\title{
Systematic Review of Member's Participation in the Co-operative Governance: What has been Studied

\author{
Mokhtaruddin Buang
}

\begin{abstract}
Co-operatives are seen as an essential economic platform for supporting development programs, and its viability is depending on members' active participation in co-operative governance. Since member participation in co-operative governance is fundamental to the organization's survival, it is necessary to review and synthesize studies from the last ten years in order to enhance our understanding of the components of member participation in co-operative governance. Following the "PRISMA Statement (Preferred Reporting Items for Systematic Reviews and Meta-Analyses)" technique, a comprehensive search of the Scopus and Web of Science databases discovered 13 relevant papers that match to the study objectives. An examination of the articles revealed two major aspects: the "supporter" who attends general meetings and the "believer" who serves on a board or committee, with these two themes forming a total of seven sub-themes. This study contributes significantly by providing an overview of the research trend in terms of member participation in cooperative governance. Second, the elements of member participation that have been studied are highlighted in this systematic review. The findings revealed that the majority of the studies focused mainly on members' participation in annual general meetings ("supporter"), with ten studies indicating that research on the participation of members serving on the board is still inadequate. Some recommendations for future research are provided to examine other elements of member participation, particularly their participation as the board members.
\end{abstract}

Keywords: Co-operative, Governance, Members, Participation

\section{INTRODUCTION}

C o-operatives have played an important role in community development [1], and their success is dependent on the level of participation of members in co-operative governance [2]-[4]. Since co-operatives are owned and controlled by their members [5] active member participation in co-operative governance is essential to the organization's functioning and survival [6]. Thus, the emphasis of this article will be on addressing member participation in co-operative governance.

The members' commitment to participate in governance can be classified into two types: attending general meetings and serving on a board or committee [7]-[9]. A general

Manuscript received on August 16, 2021.

Revised Manuscript received on August 20, 2021.

Manuscript published on August 30, 2021.

* Correspondence Author

Mokhtaruddin Buang*, Student, Department of Social and Development Sciences, Faculty of Human Ecology, Universiti Putra Malaysia Serdang, Selangor. Email: mokhtarz241981@gmail.com

(c) The Authors. Published by Blue Eyes Intelligence Engineering and Sciences Publication (BEIESP). This is an open access article under the CC BY-NC-ND license (http://creativecommons.org/licenses/by-nc-nd/4.0/) assembly, which usually takes place once a year, is where the co-operative's members come together to discuss strategic issues [8]. The "one member, one vote" principle [10], [11], which is often used by co-operatives, is an essential component of the democratic nature of co-operative decision-making [9]. Members may further increase their participation in decision-making by serving on the board of directors in addition to attending the general assembly [11]. This diagonal level of participation [12] enables a member to have a direct influence on the co-operative's strategy, policies, and initiatives [9]. Following that, [13] suggested labelling these types of participation as "supporters" who attend annual meetings and social events, and "believers" who are prospective board members.

Since member participation in co-operative internal decision-making structures through general assembly and board membership is essential, this article will synthesize work done over the last decade in accordance with member participation typology by [13] in order to evaluate the aspects that have been investigated in relation to these types of participation. This research is essential to recognize the significance of co-operative as a platform in community development initiatives through the participation of members in the governance of the co-operative. Therefore, this review enables us to synthesize and categories the relevant articles according to the categories in order to review the pattern of previous studies, providing the opportunity to explore other potential perspectives on member participation in the co-operative's strategic decision-making process.

A systematic review, according to [14], is a study of a formulated issue that utilizes systematic and explicit methods to discover, select, and critically evaluate relevant research by gathering and analysing data from previous studies. Authors' claims of accuracy in their study may be verified using this method, allowing for the discovery of gaps and suggestions for further research [15]. As a result, this systematic review will offer details on the review techniques used, as well as an overview of the parameters pertaining to the studies of the members' participation, all of which could assist future researchers in focusing on research relevant to their interest and concern. This study was driven by two major research questions in developing a proper systematic review: (1) What is the pattern from existing works and empirical studies published in the last ten years that can assist in identifying the pattern of member participation? (2) What aspects of the members' participation in the decision-making process of co-operative governance have been discussed? Blue Eyes Intelligence Engineering and Sciences Publication

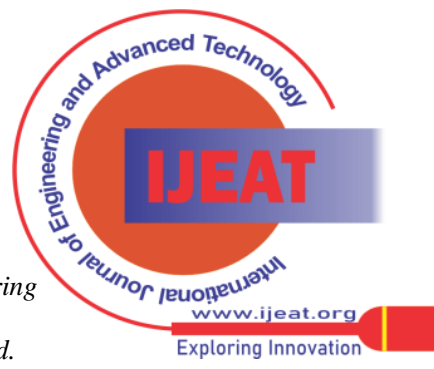




\section{METHODOLOGY}

This section covers the technique for gathering articles related to member participation in order to identify their behaviors in cooperative governance. We used the "Preferred Reporting Items for Systematic Reviews and Meta-Analyses (PRISMA)" procedure introduced by [14] to conduct the systematic review, which included inclusion and omission criteria, systematic review process (identification, screening, and eligibility), data collection and interpretation, with resources obtained through database searches.

\section{A. PRISMA Statement}

The review has been conducted in line with the PRISMA Statement. Although PRISMA is commonly utilized in the medical and healthcare sectors, [14] argue that it can also be used to perform systematic reviews in other kinds of research disciplines. It is centered on a structured question with systematic and explicit processes for identifying, selecting, and critically evaluating the research included in the review [16]. As a result, PRISMA enables an extensive search for terms related to member participation in co-operative governance.

\section{B. Resources}

The review technique used in this study is based on two major journal sources, Web of Science and Scopus (WoS). Scopus is the world's extensive database, including 22,800 publications from over 5,000 publishers. Furthermore, this database includes a broad variety of disciplines such as business, management and accounting, art and humanities, social science, and economics. WoS, on the other hand, is utilized in this research since it is a comprehensive database that includes 18,000 high-impact journals from 3,300 publishing partners, as well as more than 5,200 articles on social science spanning 55 disciplines, encompassing subjects such as economics, business, and management. Furthermore, it has almost 100 years of complete data that is fully indexed, including records and back files ranked by citations, articles, and citations per paper.

\section{Inclusion and exclusion criteria}

The criteria of inclusion and exclusion have been defined (refer Table 1). To begin, only journal articles were considered, with review articles, book series, books, book chapters, and conference proceedings being excluded. Next, to minimize misunderstanding and difficulties in translation, the study effort concentrated exclusively on papers published in English. Third, only studies conducted between 2011 and 2021 (10 years) were examined; this is a suitable time period for reviewing the development of research and related publications, since more than 5 years is sufficient for systematic review updates [17].
Table- I: The inclusion and exclusion criteria

\begin{tabular}{|c|c|c|}
\hline Criterion & Eligibility & Exclusion \\
\hline Literature type & Journal (research articles) & $\begin{array}{c}\text { Journals (systematic review), book series, } \\
\text { books, chapters in books, conference } \\
\text { proceedings }\end{array}$ \\
\hline Language & English & Non-English \\
\hline Time frame & From 2011 to 2021 & $<2011$ \\
\hline Criterion & Eligibility & Exclusion \\
\hline
\end{tabular}

\section{Process of Systematic Review}

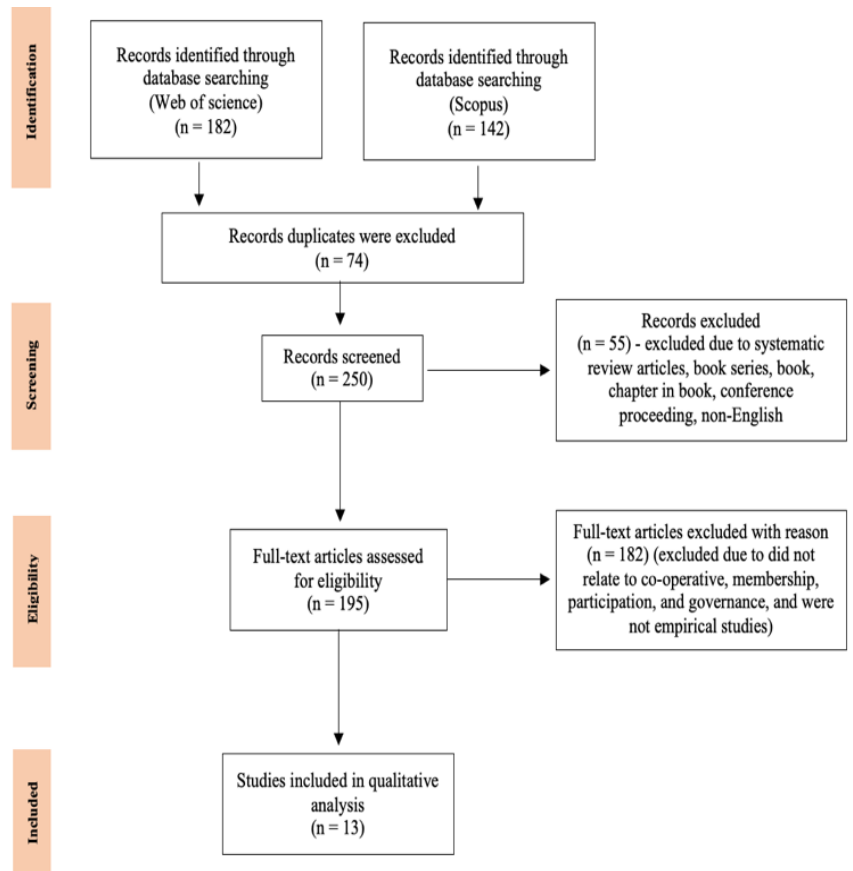

Fig. 1. The systematic review process (Adapted from Moher et al., 2010)

A four-stage systematic review process was carried out in July 2021 (see Figure 1). The initial step was to decide on the keywords, and based on prior research as well as the thesaurus, keywords similar to and linked to "co-operative," "participation," "member," and "governance" were chosen. The authors used an asterisk (*) to query the database with the keywords to discover variants in the terms, as shown in Table 2. At this point, the database search has yielded 324 articles. Duplicates (74 articles) were deleted after careful review. These duplicates were caused by similarities between journal articles from various fields that appeared in both databases.

Table- 2: The Keyword Used

\begin{tabular}{|c|l|}
\hline Database & \multicolumn{2}{|c|}{ Keyword used } \\
\hline Scopus & (TITLE-ABS-KEY ("cooperatives*" OR "co- \\
& operatives*" OR "co-ops*”) AND TITLE-ABS- \\
& KEY ("participation*" OR "involvement*" OR \\
& "engagement*") AND TITLE-ABS-KEY ("member*" \\
& OR "membership"” OR "representative*") AND \\
& TITLE-ABS-KEY ("governance*" OR \\
& "administration*" OR "control*" OR "authority*")) \\
\hline
\end{tabular}

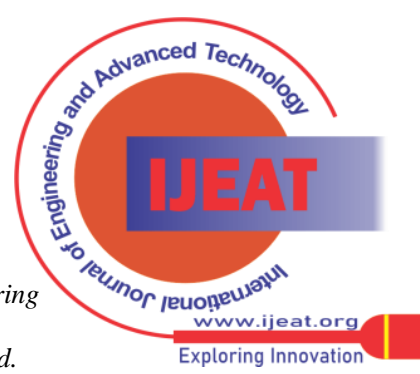




\begin{tabular}{|c|c|}
\hline Web of science & $\begin{array}{l}\text { ("cooperatives*" or "co-operatives*" } \text { or "co- } \\
\text { ops*") AND TOPIC: ("participation*" } \\
\text { "involvement*" } \\
\text { "engagement*") AND TOPIC: ("member*" } \\
\text { "membership*" or "representative*") AND TOPIC: } \\
\text { ("governance*" or "administration*" or "control*" or } \\
\text { "authority*") }\end{array}$ \\
\hline
\end{tabular}

The second step included evaluating the titles and abstracts to ensure that they were appropriate for the study objective. At this point, 55 of the 250 items eligible for review had been deleted. The final step involves determining eligibility and accessing the full articles. At this point, 182 articles were deleted due to their unsuitable content regarding member participation in co-operative governance. The last round of screening manifested 13 articles for qualitative analysis.

\section{E. Data Collection and Interpretation}

The 13 studies were examined and scrutinized, with an attention on particular studies that addressed the given objectives. The information was retrieved by first reading the abstracts and then going on to the full articles to discover the suitable topics and sub-topics based on the label of members' participation proposed by [13]. A qualitative research was conducted, and content analysis was used to classify topics and sub-topics linked to members' participation in co-operative governance. The articles were then categorized by authors, countries, title, objective, main study design, sample, and findings, as shown in Table 3.

Table- 3: Summary of reviewed studies

\begin{tabular}{|c|c|c|c|c|}
\hline $\begin{array}{c}\text { Authors } / \\
\text { Countries / Title } \\
\end{array}$ & Objective & $\begin{array}{c}\text { Main study } \\
\text { design }\end{array}$ & Sample & Findings \\
\hline $\begin{array}{l}\text { 1. Morfi, Nilsson, } \\
\text { Hakelius, \& Karantininis } \\
\text { (2021)/ Sweden/ Social } \\
\text { networks and member } \\
\text { participation in } \\
\text { cooperative governance }\end{array}$ & $\begin{array}{l}\text { To investigate the } \\
\text { relationships between } \\
\text { farmer members' social } \\
\text { networks and their } \\
\text { involvement in } \\
\text { cooperative governance }\end{array}$ & $\mathrm{QN}$ & $\begin{array}{c}2,10 \text { members of Swedish } \\
\text { agricultural co-pperatives in } \\
1993,2003 \text {, and } 2013\end{array}$ & $\begin{array}{l}\text { The findings show a } \\
\text { significant relationship } \\
\text { between social networks } \\
\text { and farmers' propensity } \\
\text { to involve in cooperative } \\
\text { governance }\end{array}$ \\
\hline $\begin{array}{l}\text { 2. Cahyyadinata, Nustil, \& } \\
\text { Gushevinalti (2020)/ } \\
\text { Indonesia / Descriptive, } \\
\text { Correlation Analysis and } \\
\text { Analytical Hierarchy } \\
\text { Process of Coastal } \\
\text { Community Empowerment } \\
\text { of Benghulu City, } \\
\text { Indonesia }\end{array}$ & $\begin{array}{l}\text { To assess the participation } \\
\text { of the members in the co- } \\
\text { operative's activities, } \\
\text { including meetings, loan } \\
\text { reppayment, and their } \\
\text { obligations }\end{array}$ & $\mathrm{QN}$ & $\begin{array}{l}61 \text { members of Coastal } \\
\text { Community Development } \\
\text { Cooperative (CCDC) }\end{array}$ & $\begin{array}{l}\text { Participation of the co- } \\
\text { operative members } \\
\text { found to be high in the } \\
\text { meetings, loan } \\
\text { repaymment, and fullil } \\
\text { obligations to sustain the } \\
\text { co-operative. }\end{array}$ \\
\hline $\begin{array}{l}\text { 3. Hakelius \& Nilsson } \\
\text { (2020) / Sweden / The } \\
\text { Logic behind the Intermal } \\
\text { Governance of Sweden's } \\
\text { Largest Agricultural } \\
\text { Cooperatives }\end{array}$ & $\begin{array}{l}\text { To investigate the } \\
\text { rationale underlying } \\
\text { cooperative governance } \\
\text { structures and to get an } \\
\text { understanding of the } \\
\text { factors that influencee } \\
\text { cooperative governance } \\
\text { structure choices }\end{array}$ & $\overline{Q L}$ & $\begin{array}{l}\text { Case suddy of two largest } \\
\text { Swedish agricultural } \\
\text { cooperatives, namely } \\
\text { Lantmännen and Södra } \\
\text { Skogsägarna }\end{array}$ & $\begin{array}{l}\text { The results suggest that } \\
\text { very large cooperatives } \\
\text { with a traditional } \\
\text { democratic member } \\
\text { governance structure } \\
\text { may succeed }\end{array}$ \\
\hline $\begin{array}{l}\text { 4. Mwambi, Bijmant, \& } \\
\text { Mshenga (2020) / Kentya / } \\
\text { Which type of producer } \\
\text { organization is (more) } \\
\text { inclusive? Dynamics of } \\
\text { farmers' membership and } \\
\text { participation in the } \\
\text { decision-making process }\end{array}$ & $\begin{array}{l}\text { To offere empirical data on } \\
\text { two inclusivity outcomes: } \\
\text { membership and } \\
\text { participation in decision- } \\
\text { making of a dairy farmer } \\
\text { cooperative in Kenya }\end{array}$ & $\mathrm{QN}$ & $\begin{array}{l}595 \text { members of dairy } \\
\text { farmet co-operative }\end{array}$ & $\begin{array}{l}\text { Findings discovered } \\
\text { that the relationship } \\
\text { between membership in } \\
\text { a processing P0 and } \\
\text { participation in decision- } \\
\text { making is } \\
\text { negative }\end{array}$ \\
\hline $\begin{array}{l}\text { 5. Sebhatu et al. (2020)/ } \\
\text { Ethiopia / Conflict, fraud, } \\
\text { and distrust in Ethiopian } \\
\text { agricultural co-operatives }\end{array}$ & $\begin{array}{l}\text { To investigate the } \\
\text { connections between } \\
\text { membership size and the } \\
\text { incidence of conflict, } \\
\text { fraud, and distrust in } \\
\text { Ethiopian agricultural } \\
\text { cooperatives }\end{array}$ & QN & $\begin{array}{c}511 \text { agricultural } \\
\text { cooperatives were }\end{array}$ & $\begin{array}{l}\text { The findings showed } \\
\text { that the size of a } \\
\text { cooperative's } \\
\text { membership has an } \\
\text { impact on its social } \\
\text { performantce in terms of } \\
\text { trust and the likelihood } \\
\text { of conflict and fraud } \\
\end{array}$ \\
\hline $\begin{array}{l}\text { 6. Lozzano, Smith, \& } \\
\text { Basurto (2019) / Mexico / } \\
\text { Weaving govermance } \\
\text { narratives: discourses of } \\
\text { climate change, } \\
\text { cooperatives, and small- } \\
\text { scale fisheries in Mexico }\end{array}$ & $\begin{array}{l}\text { To investigate how fishers } \\
\text { and govermment actors } \\
\text { dealt with climate change } \\
\text { and other socio- } \\
\text { environmental phenomena } \\
\text { in the general assemblies } \\
\text { of federated fishing co- } \\
\text { operatives }\end{array}$ & $\mathrm{QL}$ & $\begin{array}{l}\text { Ethnographic observation - } \\
\text { The } 2016 \text { assembly of } \\
\text { CONMECOOP }\end{array}$ & $\begin{array}{l}\text { The variety of discursive } \\
\text { strategies used by } \\
\text { fishermen and } \\
\text { governiment actoris at } \\
\text { CONMECOOP general } \\
\text { meetings demonstrates } \\
\text { how the sector's identity, } \\
\text { roles of actors, and } \\
\text { perspectives on topics } \\
\text { like climate change are } \\
\text { discussed }\end{array}$ \\
\hline
\end{tabular}

\begin{tabular}{|c|c|c|c|c|}
\hline $\begin{array}{l}\text { 7. Kleanthous, Paton, \& } \\
\text { Wilson (2019) / Cyprus / } \\
\text { Credit unions, co- } \\
\text { operatives, sustainability, } \\
\text { and accountability in a } \\
\text { time of change: A case } \\
\text { study of credit unions in } \\
\text { Cyprus }\end{array}$ & $\begin{array}{l}\text { To investigate how } \\
\text { cooperative principles } \\
\text { influenced decision } \\
\text { making, governance, } \\
\text { accountability, and } \\
\text { sustainability of credit } \\
\text { unionss in Cyprus }\end{array}$ & $\mathrm{QL}$ & $\begin{array}{l}\text { Structured interviews - } 4 \\
\text { genereral managagers, } 6 \\
\text { managers and } 20 \text { staff, } \\
\text { and focus group - } 20 \\
\text { males and } 10 \text { females }\end{array}$ & $\begin{array}{l}\text { The results indicate that } \\
\text { low membership } \\
\text { participation weakens } \\
\text { governance and that the } \\
\text { co-operative principles } \\
\text { are to longer uniformly } \\
\text { followed by credit } \\
\text { unions in Cyprus }\end{array}$ \\
\hline $\begin{array}{l}\text { 8. Berge, Caldwell, \& } \\
\text { Mount (2016)/ Canada / } \\
\text { Governance of nine } \\
\text { Ontario food co-operatives }\end{array}$ & $\begin{array}{l}\text { To examine whether the } \\
\text { theory of cyclical board } \\
\text { behaviour may offer } \\
\text { insight into the } \\
\text { development of boards } \\
\text { within food co-operatives }\end{array}$ & $\overline{\mathrm{QL}}$ & $\begin{array}{l}\text { Semi-structured interview } \\
-9 \text { managers }\end{array}$ & $\begin{array}{l}\text { Board member } \\
\text { participation, succession } \\
\text { planning, and defining } \\
\text { board member duties } \\
\text { and responsibilities are } \\
\text { among the most urgent } \\
\text { governance issues facing } \\
\text { food co-operatives in } \\
\text { Ontario, Canada. }\end{array}$ \\
\hline $\begin{array}{l}\text { 9. Liang, Hendrikse, } \\
\text { Huang, \& Xu (2015)/ } \\
\text { China / Governance } \\
\text { structure of Chinese } \\
\text { farmer cooperatives: } \\
\text { Evidence from Zhejiang } \\
\text { Province }\end{array}$ & $\begin{array}{l}\text { To examine provisions in } \\
\text { the Law in China } \\
\text { concerning the governance } \\
\text { structure of fammer co- } \\
\text { operatives and provide } \\
\text { data in terms of ownership } \\
\text { rights, decision rights, and } \\
\text { income rights to define } \\
\text { and assess the compliance } \\
\text { of co-operative activities } \\
\text { with the Law }\end{array}$ & $\overline{\mathrm{QN}}$ & $\begin{array}{l}37 \text { fruit and vegetable co- } \\
\text { operatives }\end{array}$ & $\begin{array}{l}\text { Findings showed } \\
\text { that several governance } \\
\text { practices by co- } \\
\text { operatives are not in line } \\
\text { with the requirements } \\
\text { specified by the Law }\end{array}$ \\
\hline $\begin{array}{l}\text { 10. Verhees, Sergaki, \& } \\
\text { Van Dijk (2015) / } \\
\text { Netherlands / Building up } \\
\text { active membership in co- } \\
\text { operatives }\end{array}$ & $\begin{array}{l}\text { To examine the social } \\
\text { attributes that transform } \\
\text { memembers into active } \\
\text { members }\end{array}$ & $\mathrm{QN}$ & $\begin{array}{l}241 \text { members of a Dutch } \\
\text { feed supply cooperative }\end{array}$ & $\begin{array}{l}\text { According to the } \\
\text { findings, active } \\
\text { membership relies on } \\
\text { social characteristics } \\
\text { such as co-operative } \\
\text { culture, open } \\
\text { communication, trust, } \\
\text { participation, and a } \\
\text { desire to be active }\end{array}$ \\
\hline $\begin{array}{l}\text { 11. Cechin, Bijman, } \\
\text { Pascussi, Zybersztajn, \& } \\
\text { Omta (2013) / Brazil / } \\
\text { Drivers of pro-actives } \\
\text { member participation in } \\
\text { agricultural cooperatives: } \\
\text { Evidence from Brazil }\end{array}$ & $\begin{array}{l}\text { To determine if farmers' } \\
\text { economic motivations for } \\
\text { continued membership in } \\
\text { a co-operative are relevant } \\
\text { drivers of pro-active } \\
\text { participation }\end{array}$ & $\mathrm{QN}$ & $\begin{array}{c}148 \text { farmers from } \\
\text { agricultural co-operative }\end{array}$ & $\begin{array}{l}\text { The findings indicate } \\
\text { that economic incentives } \\
\text { for continuing } \\
\text { membership motivate } \\
\text { participation in the } \\
\text { General Assembly, but } \\
\text { not in 'pro-active' boards } \\
\text { and committees. }\end{array}$ \\
\hline $\begin{array}{l}\text { 12. Pozzobon \& } \\
\text { Zylbersztajn (2013)/ } \\
\text { Brazil / Democratic costs } \\
\text { in member-controlled } \\
\text { organizations }\end{array}$ & $\begin{array}{l}\text { To investigate the costs of } \\
\text { democratic control, which } \\
\text { is a significiant element } \\
\text { influencing traditional } \\
\text { agricultural co-operatives' } \\
\text { competitiveness. }\end{array}$ & $\mathrm{QL}$ & $\begin{array}{c}\text { Semi structured } \\
\text { interviews - Managers } \\
\text { from } 12 \text { agricultural co- } \\
\text { operatives }\end{array}$ & $\begin{array}{l}\text { Results showed that the } \\
\text { level of board } \\
\text { heteteogeneity yffects } \\
\text { demmoctatitic costs } \\
\text { indirectly, whereas the } \\
\text { level of member } \\
\text { participation in the } \\
\text { genereral assembly } \\
\text { influenceses democtatic } \\
\text { costs directly }\end{array}$ \\
\hline $\begin{array}{l}\text { 13. Barraud-Didier, } \\
\text { Hennininger, \& El Akremi } \\
\text { (2012)/French / The } \\
\text { relationship between } \\
\text { members' trust and } \\
\text { participation in the } \\
\text { governance of } \\
\text { cooperatives: The role of } \\
\text { organizational } \\
\text { commitment }\end{array}$ & $\begin{array}{l}\text { To explore and test the } \\
\text { mediator role of } \\
\text { organizational } \\
\text { commitment in the } \\
\text { relationship between trust } \\
\text { and members' } \\
\text { participation in the } \\
\text { governance of French } \\
\text { agricultural co-operatives }\end{array}$ & $\overline{\mathrm{QN}}$ & $\begin{array}{l}259 \text { farmer-members from } \\
\text { French agricultural } \\
\text { cooperatives }\end{array}$ & $\begin{array}{l}\text { The findings revealed } \\
\text { that affective } \\
\text { commitment acted as a } \\
\text { mediator in the } \\
\text { relationship between } \\
\text { trust and participation in } \\
\text { cooperative governantice. }\end{array}$ \\
\hline
\end{tabular}

\section{RESULT AND DISCUSSION}

The review yielded two major themes and seven sub-themes relating to member participation. The two major themes are "supporters," which refers to behavior connected with general assembly activities, and "believers," which refers to board member elements., as shown in Table 4.

Three research examined member participation in Asian nations, whereas four studies were performed in European countries, including the Netherlands, France, and Sweden. Similarly, four research were conducted in the Americas, particularly in Mexico and Brazil, while the other two studies were undertaken in African countries, specifically Kenya and Ethiopia.

Furthermore, eight research utilized a quantitative method, while the remaining five used qualitative analytical approaches. In terms of publication years, one article was published in 2021, four articles have been released in 2020, two research were performed in 2019, 2015, and 2013, and one study was conducted in each of 2016 and 2012.

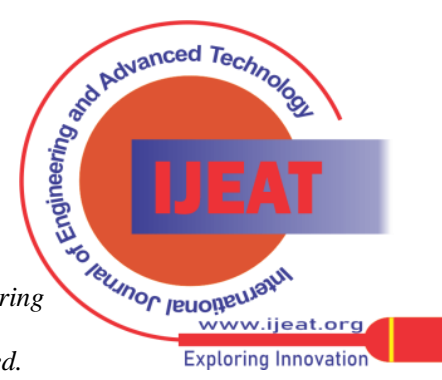


There was no publication in 2018, 2017, 2014, or 2011 (Figure 2). Based on the findings, the overall results showed that studies on member participation in co-operative governance are still limited and insufficient. This has resulted in limited information regarding members' participation in the co-operative governance.

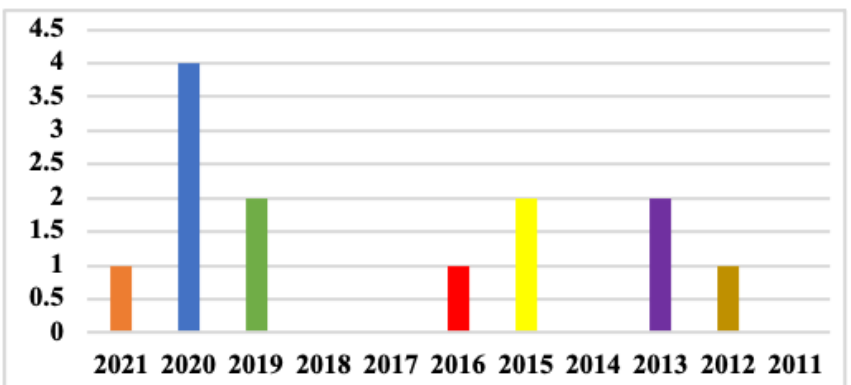

Fig. 2. Number of articles published by year

In addition, Table 4 summarizes the findings of the reviewed studies which include member participation as a "supporter" and "believer".

Table- 4: The finding

\begin{tabular}{|c|c|c|c|c|c|c|c|c|}
\hline & \multirow{2}{*}{$\begin{array}{l}\text { Authors/ } \\
\text { Countries }\end{array}$} & \multicolumn{4}{|c|}{ "Supporter" } & \multicolumn{3}{|c|}{ "Believer" } \\
\hline & & $\begin{array}{l}\text { Attending } \\
\text { the AGM }\end{array}$ & $\begin{array}{c}\text { Speaking } \\
\text { up in the } \\
\text { AGM }\end{array}$ & $\begin{array}{l}\text { Voting } \\
\text { in the } \\
\text { AGM }\end{array}$ & $\begin{array}{c}\text { Number } \\
\text { of } \\
\text { meetings }\end{array}$ & $\begin{array}{l}\text { Serving on } \\
\text { the board }\end{array}$ & $\begin{array}{l}\text { Board } \\
\text { size }\end{array}$ & $\begin{array}{l}\begin{array}{l}\text { The role } \\
\text { of the } \\
\text { board }\end{array} \\
\end{array}$ \\
\hline 1. & $\begin{array}{l}\text { Morfi, Nilsson, } \\
\text { Hakelius, \& } \\
\text { Karantininis } \\
\text { (2021)/ Sweden }\end{array}$ & & & & & $\checkmark$ & & \\
\hline 2. & $\begin{array}{l}\text { Cahyadinata, } \\
\text { Nusril, \& } \\
\text { Gushevinalti } \\
(2020) / \text { Indonesia }\end{array}$ & $\checkmark$ & & & & & & \\
\hline 3. & $\begin{array}{l}\text { Hakelius \& } \\
\text { Nilsson (2020) / } \\
\text { Sweden }\end{array}$ & & & & & & $\checkmark$ & \\
\hline 4. & $\begin{array}{l}\text { Mwambi, Bijman, } \\
\text { \& Mshenga } \\
(2020) / \text { Kenya }\end{array}$ & $\checkmark$ & $\checkmark$ & & & $\checkmark$ & & \\
\hline 5. & $\begin{array}{l}\text { Sebhatu et al. } \\
\text { (2020)/Ethiopia }\end{array}$ & & & & $\checkmark$ & & & \\
\hline 6. & $\begin{array}{l}\text { Lozano, Smith, \& } \\
\text { Basurto (2019)/ } \\
\text { Mexico }\end{array}$ & $\checkmark$ & & & & & & \\
\hline 7. & $\begin{array}{l}\text { Kleanthous, } \\
\text { Paton, \& Wilson } \\
\text { (2019) / Cyprus }\end{array}$ & $\checkmark$ & & $\checkmark$ & & & & \\
\hline 8. & $\begin{array}{l}\text { Berge, Caldwell, } \\
\& \text { Mount (2016)/ } \\
\text { Canada }\end{array}$ & & & & & & & $\checkmark$ \\
\hline 9. & $\begin{array}{l}\text { Liang, Hendrikse, } \\
\text { Huang, \& Xu } \\
\text { (2015)/China }\end{array}$ & & & $\checkmark$ & & & & \\
\hline 10. & $\begin{array}{l}\text { Verhees, Sergaki, } \\
\& \text { Van Dijk } \\
\text { (2015)// } \\
\text { Netherlands }\end{array}$ & $\checkmark$ & & & & & & \\
\hline 11. & $\begin{array}{l}\text { Cechin, Bijman, } \\
\text { Pascussi, } \\
\text { Zybersztajn, \& } \\
\text { Omta (2013)/ } \\
\text { Brazil } \\
\end{array}$ & & & $\checkmark$ & & $\checkmark$ & & \\
\hline 12. & $\begin{array}{l}\text { Pozzobon \& } \\
\text { Zylbersztajn } \\
\text { (2013)/ Brazil } \\
\end{array}$ & $\checkmark$ & & & & & $\checkmark$ & \\
\hline 13. & $\begin{array}{l}\text { Barraud-Didier, } \\
\text { Henninger, \& El } \\
\text { Akremi (2012)/ } \\
\text { French } \\
\end{array}$ & $\checkmark$ & $\checkmark$ & $\checkmark$ & & & & \\
\hline
\end{tabular}

\section{A. "Supporter"}

Ten of the 13 studies focused on the elements that influence members' participation at annual general meetings (AGM). Attending the AGM was shown to be the most common behavior of members' participation as a "supporter" in eight studies, while voting in the AGM was found to be an indication of member participation in the co-operative's governance in four studies. Aside from that, two studies emphasized the action of speaking up at the AGM as member involvement in the co-operative's decision-making process. (Table 4). [18] discovered that the degree of participation of Coastal Community Development Cooperative members in Bengkulu City, Indonesia, was affected by family income in their recent research. Furthermore, they found that members' business experience was positively linked with attending the AGM, which is comparable to the research performed by [19]. Another point that has been addressed is the voting at the AGM. Voting at the general assembly is an important element of the democratic character of co-operative decision making, and most co-operatives follow the 'one-member-one-vote' principle [9]-[11], [20]. According to [11], the annual assembly is one of the members' avenues of expression, ensuring that the co-operative is managed democratically, including the election of board members, voting on key strategic choices, and approving the co-operative's annual financial report [9]. Speaking up is the third aspect that has been assessed in terms of members' participation at the AGM [11], [19]. Based on an analysis of 595 smallholder dairy farmers co-operative in Kenya, [19] discovered that members' desire to speak up at the AGM is influenced by their trust in the co-operative represented, i.e., the directors, as supported by [11], that competently meets the members' needs and creates added value to their benefit [21]. Meanwhile, in the context of Ethiopian agricultural co-operatives, member participation is measured based on the number of general assembly meetings held, and [22] discovered that the level of participation is lower in large co-operatives due to members not being informed about the meetings due to the sheer number of members.

\section{B. "Believer"}

The results of this study also revealed that six studies focused on members' participation in co-operative governance in connection to the board of directors' aspect. This theme yielded three sub-themes: serving on the board, board size, and board role. Three studies demonstrated the form of member participation through serving on the board [9], [19], [23], while two studies highlighted the effect of board size on the strategic decision-making process of the co-operative [8], [12]. Furthermore, two sub-themes emerged, with one research for each, namely the aspect of board candidate election [24] and the role of the board [20] (refer Table 4). According to the most current study [23], the variables used in evaluating member participation on the board were based on "potential involvement" and "actual involvement." Members' "potential involvement" pertains to their intention to serve as an elected representative. Meanwhile, "actual involvement" relates to the election of board members, also known as pro-active participation, in which comparable metrics have been used in research conducted by [9] and [19]. Furthermore, [20] highlighted the significant role played by the board in the governance of nine Ontario food co-operatives in their study on the governance of co-operatives based on the co-operative's life cycle proposed by [25], which includes: 1) Founding Phase: Collective, 2) Supermanaging Phase, and 3) Corporate Phase.

Blue Eyes Intelligence Engineering and Sciences Publication

(C) Copyright: All rights reserved.

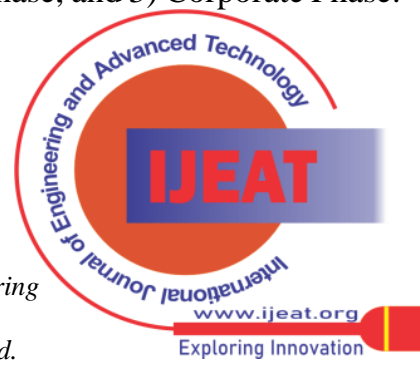


The foundation phase is divided into two intervals: a) the collective interval, where the firm is managed by the governing board, and b) the sustaining interval, in which an owner-executive is in place to operate the business. When a board reaches the supermanaging phase, it takes on a more prominent role, including controlling the business to ensure that it follows the board's instructions. A corporate phase occurs when the board of directors takes a step back and allows management to take on more duties as the firm's appropriate manager.

To summarize, according to the findings in Table 4, members' participation in annual general meetings or as "supporter" are the most observed elements in the articles reviewed, with 10 studies covering four sub-themes: attending the AGM, voting in the AGM, speaking up in the AGM, and number of meetings. The second category is "believer," in which six studies were conducted on members' participation in co-operative governance in relation to the board of directors' aspect; three sub-themes formed, namely, serving on the board, board size, and board role.

\section{CONCLUSION}

This systematic study emphasized the pattern from previous works and empirical research published in the last ten years, as well as an effort to identify the elements in understanding members' participation in co-operative governance. After analyzing the aforementioned literature on member participation, the overall findings showed that the studies are still insufficient, as shown in Figure 2. As a result, since such studies are currently insufficient, this offers up a new route for an empirical research on member participation in co-operative governance.

Furthermore, prior researchers have proposed various aspects of member participation in co-operative governance within the time frame of the reviews. Based on the systematic reviews, the authors discovered seven elements that were classified into two categories: "supporter" and "believer." However, as indicated in Table 4, most of the research (ten studies) focused on evaluating the impact of members' participation in annual general meetings.

Nonetheless, [26] has emphasized the significance of examining board participation behavior, particularly in the strategic decision-making process, in the context of corporate governance. According to [27], the board's participation occurred retrospectively in two main phases: the formulation phase of the strategic decision process and the assessment phase of monitoring operations. [26] went on to explain how board participation could influence the firm's strategy in two ways: through decision control such as strategic plan review, monitoring executive and firm performance tracking [28], and management activities such as ratification of strategic suggestions, questioning significant problems, and helping to formulate, evaluate, and decide [27].

Similarly, in the setting of cooperative governance, the appointed members of the board are responsible for monitoring management efficiency, developing long-term strategic plans, assessing management recommendations, and comprehending the organization's monetary and strategic actions [29], which is comparable to [30] in describing the co-operative's main tasks.

Since co-operatives play an essential role in community development initiatives due to their more community-oriented character [31], [32], their viability is dependent on the active participation of board members in carrying out their duties effectively. Subsequently, participation theory of community development was suggested as a suitable framework for analyzing board member participation by [33] was suggested to analyze board member participation.

[33] describe participation as a process in which a number of people are engaged in program decision-making and implementation, as well as participation in assessment activities where individual voluntary and democratic engagement is needed [34]. Following that, this theory provides a framework for identifying three levels of participation that address the following concerns: (1) 'What' types of participation occur, (2) 'Who' participates in them, and (3) 'How' the participation process occurs [35]. Since this research focused on board members' participation in strategic decision-making, the emphasis will be on the 'What' dimension, which can be operationalized into four measurable dimensions, namely planning, implementation, benefit sharing, and monitoring and evaluation [35], [36]. Nonetheless, due to a contradiction between its practicality [37] and the passive type of participation [33], the benefit participation element was removed.

Although many studies have emphasized members' participation in co-operative governance in relation to the board of directors [8], [9], [12], [19], [20], [23], these studies do not address board involvement in the strategic decision-making process, which has the potential to be explored in depth.

Therefore, future research should investigate concentrating on the viewpoint of board participation in the strategic decision-making process, which includes planning, execution, monitoring, and evaluation, as this has yet to be examined. By examining the effect of member participation as the co-operative board in improving its strategies as the economy's third-largest contributing sector, fresh insights into the co-operative context will be offered.

\section{REFERENCES}

1. K. Zeuli, D. Freshwater, D. Markley, and D. Barkley, "Cooperatives in Rural Community Development: A New Framework for Analysis," J. Community Dev. Soc., vol. 35, no. 2, pp. 17-35, 2004.

2. A. M. Amini and M. Ramezani, "Investigating the Success Factors of Poultry Growers' Cooperatives in Iran's Western Provinces," World Appl. Sci. J., vol. 5, no. 1, pp. 81-87, 2008.

3. Y. M. 'Aini, H. A. K. Hafizah, and Y. Zuraini, "Factors Affecting Cooperatives' Performance in Relation to Strategic Planning and Members' Participation," Procedia - Soc. Behav. Sci., vol. 65, pp. 100-105, 2012.

4. Sushila Devi Rajaratnam, N. Noordin, M. S. A. Said, R. Juhan, and F. M. Hanif, "Success Factors of Cooperatives In Malaysia: An Exploratory Investigation," Malaysian J. Co-op. Manag., vol. 5, no. 1, pp. 1-24, 2010.

5. J. R. Dunn, "Basic cooperative principles and their relationship to selected practices," J. Agric. Coop., vol. 3, no. 1141-2016-92562, pp. 83-93, 1988.

6. R. Spear, "Governance in democratic member-based organisations," Ann. public Coop. Econ., vol. 75, no. 1, pp. 33-60, 2004.

7. J. Bijman, M. Hanisch, and G. van der Sangen, "Shifting control? The changes of internal governance in agricultural cooperatives in the EU,”Ann. Public Coop. Econ., vol. 85, no. 4, pp. 641-661, Dec. 2014.

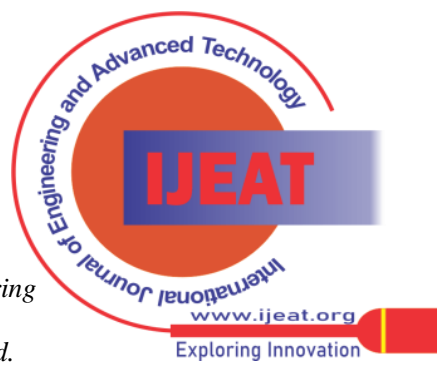


8. K. Hakelius and J. Nilsson, "The Logic behind the Internal Governance of Sweden's Largest Agricultural Cooperatives,' Sustainability, vol. 12, no. 21, p. 9073, 2020.

9. A. Cechin, J. Bijman, S. Pascussi, D. Zybersztajn, and O. Omta, "Drivers of pro-actives member participation in agricultural cooperatives: Evidence from Brazil," Ann. Public Coop. Econ., vol. 84, no. 4, pp. 443-468, Dec. 2013.

10. Q. Liang, G. Hendrikse, Z. Huang, and X. Xu, "Governance structure of chinese farmer cooperatives: Evidence from Zhejiang Province," Agribusiness, vol. 31, no. 2, pp. 198-214, 2015.

11. V. Barraud-Didier, M.-C. Henninger, and A. El Akremi, "The Relationship Between Members' Trust and Participation in the Governance of Cooperatives: The Role of Organizational Commitment," Int. Food Agribus. Manag. Rev., vol. 15, no. 1, pp. 1-24, 2012.

12. D. M. Pozzobon and D. Zylbersztajn, "Democratic Costs in Member-Controlled Organizations,” Agribusiness, vol. 29, no. 1, pp. 112-132, Dec. 2013.

13. J. Birchall and R. Simmons, "What motivates members to participate in co-operative and mutual businesses?," Ann. Public Coop. Econ., vol. 75, no. 3, pp. 465-495, 2004.

14. D. Moher, A. Liberati, J. Tetzlaff, and D. G. Altman, "Preferred reporting items for systematic reviews and meta-analyses: The PRISMA statement," Int. J. Surg., vol. 8, no. 5, pp. 336-341, 2010.

15. H. A. M. Shaffril, S. E. Krauss, and S. F. Samsuddin, "A systematic review on Asian's farmers' adaptation practices towards climate change," Science of the Total Environment, vol. 644. pp. 683-695, Dec-2018.

16. J. Higgins and S. Green, Cochrane Handbook for Systematic Reviews of Interventions, no. 4. 2006.

17. R. Bashir, D. Surian, and A. G. Dunn, "Time-to-update of systematic reviews relative to the availability of new evidence," Syst. Rev., vol. 7 , no. 1, p. 195, 2018.

18. I. Cahyadinata, Nusril, and Gushevinalti, "Descriptive, correlation analysis and analytical hierarchy process of coastal community empowerment of Bengkulu City, Indonesia," Int. J. Adv. Sci. Eng. Inf. Technol., vol. 10, no. 3, pp. 1304-1310, 2020.

19. M. Mwambi, J. Bijman, and P. Mshenga, "Which type of producer organization is (more) inclusive? Dynamics of farmers' membership and participation in the decision-making process," Ann. Public Coop. Econ., vol. 91, no. 2, pp. 213-236, 2020.

20. S. Berge, W. Caldwell, and P. Mount, "Governance of nine Ontario food co-operatives," Ann. Public Coop. Econ., vol. 87, no. 3, pp. 457-474, 2016.

21. L. Theuvsen and A. Franz, "The role and success factors of livestock trading cooperatives: lessons from German pork production," Int Food Agribus. Manag. Rev., vol. 10, no. 1030-2016-82515, pp. 90-112, 2007

22. K. T. Sebhatu, T. W. Gezahegn, T. Berhanu, M. Maertens, S. Van Passel, and M. D'Haese, "Conflict, fraud, and distrust in Ethiopian agricultural cooperatives," J. Co-op. Organ. Manag., vol. 8, no. 1, p. 100106, 2020.

23. C. Morfi, J. Nilsson, K. Hakelius, and K. Karantininis, "Social networks and member participation in cooperative governance," Agribusiness, vol. 37, no. 2, pp. 264-285, 2021.

24. A. Kleanthous, R. A. Paton, and F. M. Wilson, "Credit unions, co-operatives, sustainability and accountability in a time of change: A case study of credit unions in Cyprus," Int. J. Soc. Econ., 2019.

25. M. M. Wood, "Is governing board behavior cyclical?," Nonprofit Manag. Leadersh., vol. 3, no. 2, pp. 139-163, 1992.

26. M. K. Fiegener, "Determinants of board participation in the strategic decisions of small corporations," Entrep. Theory Pract., vol. 29, no. 5 , pp. 627-650, Sep. 2005.

27. W. Q. Judge and C. P. Zeithaml, "Institutional and strategic choice perspectives on board involvement in the strategic decision process.," Academy of Management journal. Academy of Management, vol. 35 no. 4. pp. 766-794, Oct-1992.

28. E. F. Fama and M. C. Jensen, "Agency problem and residual claims," J. Law Econ., vol. 26, no. 2, pp. 1-29, Jun. 1983.

29. J. Keeling Bond, "Cooperative Financial Performance and Board of Director Characteristics : A Quantitative Investigation,” J. Coop., vol. 22, pp. 20-35, 2009.

30. K. Hakelius, "Understanding the board of Swedish farmer cooperatives - Cases focusing on board composition and interaction patterns," J. Co-op. Organ. Manag., vol. 6, no. 2, pp. 45-52, Jul. 2018.

31. B. Fairbairn, Co-operatives and community development: Economics in social perspective. Univ of Saskatchewan, 1991.

32. P. Wilkinson and J. Quarter, Building a community-controlled economy: The Evangeline co-operative experience. University of

Published By:

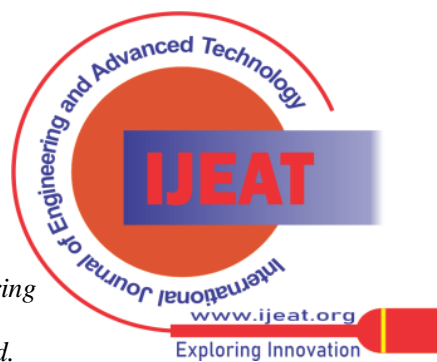

J. Cohen and N. Uphoff, Rural Development Participation: Concepts and Measures for Project Design, Implementation, and Evaluation. 1977.

34. H. A. Nikkhah and M. Redzuan, "Participation as a Medium of Empowerment in Community Development," Eur. J. Soc. Sci., vol. 11, no. 1, pp. 170-176, 2009.

35. J. Cohen and N. Uphoff, "Participation's s place in rural development : Seeking clarity through specificity," World Dev., vol. 8, pp. 213-235, 1980

A. Abu Samah and A. Fariborz, "The Theoretical and Conceptual Participation in Processes of Community Development in Malaysia," J. Am. Sci., vol. 7, no. 2, pp. 186-195, 2011.

7. M. J. Sheikh, "Farmers' Participation, Social Capital, and Benefits in Water Management in Sindh Province of Pakistan," Universiti Putra Malaysia, 2015.

\section{AUTHORS PROFILE}

Mokhtaruddin bin Buang, is a $\mathrm{PhD}$ student at the Department of Social and Development Sciences a the Faculty of Human Ecology, Universiti Putra Malaysia (UPM). He obtained his Bachelor of Business Administration in Production and Operations Management in 2004 and his Master of Business Administration in Human Resource Management in 2013. 